\title{
Biological properties of black mulberry-derived food products (Morus nigra L.)
}

\author{
Kucelova Lucia ${ }^{\mathrm{a}}$, Grygorieva Olga ${ }^{\mathrm{b}}$, Ivanišová Eva ${ }^{\mathrm{c}, *}$, Margarita Terentjeva ${ }^{\mathrm{d}}$ and Brindza Ján ${ }^{\mathrm{a}}$ \\ ${ }^{a}$ Institute of Biodiversity Conservation and Biosafety, Faculty of Agrobiology and Food Resources, \\ Slovak University of Agriculture in Nitra, Slovakia \\ ${ }^{\mathrm{b}}$ M.M. Gryshko National Botanical Garden of Ukraine of National Academy of Sciences, Kyiv, Ukraine \\ ${ }^{\mathrm{c}}$ Department of Plant Storage and Processing, Faculty of Biotechnology and Food Sciences, Slovak University \\ of Agriculture in Nitra, Slovakia \\ ${ }^{\mathrm{d}}$ Institute of Food, Environmental Hygiene, Faculty of Veterinary Medicine Latvia University of Agriculture, \\ Jelgava, Latvia
}

Received 9 January 2016; accepted 24 April 2016

\begin{abstract}
.
BACKGROUND: Black mulberry is a good source of bioactive compounds and especially of anthocyanin.

OBJECTIVES: The objective of this study was to evaluate the morphological, biochemical, technological and antioxidant properties of black mulberry fruit and fruit-derived food products.

MATERIALS AND METHODS: Total anthocyanin content, total sugar content, ascorbic acid content, pH and antioxidant activity was analyzed in black mulberry juice, jam, jelly, syrup, liqueur, compote, wine and cake. All products were produced from selected genotypes of black mulberry grown in Slovakia.

RESULTS: Reducing sugar content ranged from $6.50 \mathrm{mg} \cdot \mathrm{kg}^{-1} \mathrm{FM}$ in wine to $60.01 \mathrm{mg} \cdot \mathrm{kg}^{-1} \mathrm{FM}$ in jam, ascorbic acid content was from $0.27 \mathrm{mg} .100 \mathrm{~g}^{-1} \mathrm{FM}$ in wine to $1.10 \mathrm{mg} .100 \mathrm{~g}^{-1} \mathrm{FM}$ in fruits conserved in honey without sterilization. Content of anthocyanin varied from 21.4 in wine to $106.4 \mathrm{mg} . \mathrm{dm}^{-3}$ in fresh juice. Detected $\mathrm{pH}$ values ranged from 3.28 in jelly to 3.69 in liqueur. All tested samples had strong DPPH radical scavenging activity with the best values in black mulberry compote with honey $-74.02 \%$ and jam $71.22 \%$ FM. Differences between the genotypes were significant and the content of the anthocyanin was significantly higher in genotypes with lower fruit weight $(P \leq 0.05)$.

CONCLUSION: The results showed that black mulberry fruits and derived products are rich in biologically active compounds and can be used in food industry and human nutrition.
\end{abstract}

Keywords: Antioxidant, anthocyanin, pH, sugar, ascorbic acid, black mulberry

\section{Introduction}

Black mulberry (Morus nigra L.) is a member of genus Morus of Moraceae family [1,2]. Naturally the black mulberry populations are distributed in the Middle East [3]. The leaves of the black mulberry were used for feeding of silkworms in the regions of East, Middle and South Asia [4]. This tree can achieve the height up to $8-12 \mathrm{~m}$

\footnotetext{
${ }^{*}$ Corresponding author: Ivanišová Eva, Department of Plant Storage and Processing, Faculty of Biotechnology and Food Sciences, Slovak University of Agriculture in Nitra, Slovakia. E-mail: eva.ivanisova@uniag.sk.
} 
forming a very dense globular crown with a diameter over $10 \mathrm{~m}$ [5]. Flowering time is from May to June and the fruit is represented by fruitage with a length and width up to 40 and $25 \mathrm{~mm}$, respectively. Average weight of fruits is $3.74-5.67 \mathrm{~g}$, width $15.73-17.42 \mathrm{~mm}$ and length $21.66-27.04 \mathrm{~mm}$ [6]. Maturation time starts in August and terminates in September. Alongside with high nutritional level [3], berries possess fresh odour and sweet, sour and unique piquant taste [7] Protein concentration per dry weight of fruits is $0.96 \pm 0.16 \mathrm{~g} .100 \mathrm{~g}^{-1}$, total carbohydrates $13.83 \pm 1.20 \mathrm{~g} .100 \mathrm{~g}^{-1}$, lipids $0.55 \pm 0.06 \mathrm{~g} .100 \mathrm{~g}^{-1}$ and fibre $11.75 \pm 1.21 \mathrm{~g} .100 \mathrm{~g}^{-1}$ [8]. Energy value related to the fresh weight is $64.11 \pm 2.45 \mathrm{kcal} 100 \mathrm{~g}^{-1}$. In $100 \mathrm{~g}$ of fruits were found the following amounts of substances: Content of thiamine, riboflavin and vitamin C was $0.04 \mathrm{mg} .100 \mathrm{~g}^{-1}, 0.08 \mathrm{mg} .100 \mathrm{~g}^{-1}$, and $30 \mathrm{~g} .100 \mathrm{~g}^{-1} \mathrm{in} 100 \mathrm{~g}$ of fruits [9]. Total amount of phenols comprised $880 \pm 7.20 \mathrm{mg} .100 \mathrm{~g}^{-1}$ and alkaloids $630 \pm 5.93 \mathrm{mg} .100 \mathrm{~g}^{-1}$ per fresh weight [8]. Black mulberry fruits contain high amount of water-up to $82.4 \%$ during the maturation [8] The high content of water makes the fruits perishable and therefore sensitive to storage conditions. For extanding the shelf-life of berries various types of conservation or processing are applied to produce the stable products. The juice preparation is the most frequently used method for berry processing in Slovakia alongside with drying, production of concentrated juice, jelly and/or marmalade. The processing of fruits should be initiated without any delay because the non-washed mulberry fruit can be stored for a few days in refrigerator.

For the food industry needs both fruits and leaves are important. Products of blackberry fruits processing are jams, juices, syrups, wine, distillates or canned goods [10]. However, all plant parts of Morus plant are traditionally used in Chinese medicine [11] to heal asthma, bronchitis, cough, cold, constipation, epilepsy, headache, glycaemia, hypertensia, dizziness and wound healing [12]. Moreover, application of Morus berries helps to reduce a concentration of uric acid concentration and this allow to use the plant for the gout treatment. Berries effectively reduce the cholesterol and triacylglycerols level in blood. Presence of proanthocyanins and anthocyanes makes the fruit suitable for application in some types of cancer and have positive effect on regeneration of tissues after the ischemic stroke [7], and supports the kidney function [11,13]. Berries may be applied for therapy of incontinency, for prevention of early grayness and constipation, [11] dysentery, toothache or it could be applied as laxative or emetic agent. Black mulberry plants are a source of phenols, which possess multiple biological properties - they exhibit antioxidative, antimutagenic and anticarcinogenic action and are able to change the genes expression under some conditions [14]. Black mulberry fruits and other plant parts are valuable products in Turkey as well - used in folk medicine for fever and blood pressure reduction and liver protection [3]. There are generally characterized by good digestion, narcotic and antitoxic properties [10]. The leaves contain high amount of calcium carbonate, adenine, glucose, mineral salts and tannin with antibacterial effects; hence, applied for treatment of cold and fever, headache, for stimulation of the insulin production [5], in cases of snake bites or as antidote in case of poisoning with Aconitum napellus [15].

Shoots possess antirheumatic properties, they are used as analgesic agent and for reduction of blood pressure. The bark anesthetic action and used for pain relief in case of toothache and in the traditional medicine the bark extract reveal antiparasitic effect [15].

The aim of this study was to evaluate morphological characteristic of selected genotypes of black mulberry fruits grown in Slovakia, as well as biochemical, technological and antioxidant properties of different products prepared from the black mulberry fruits.

\section{Materials and methods}

\subsection{Biological material}

Black mulberry (Morus nigra L.) fruits (unknown local varieties) were collected in 2015 from trees growing in the Pukanec village localized in Central Slovakia at an altitude of 330-480 m above the sea level. The ripened fruits were picked from trees, the berries were evaluated for uniformity of the color and then transported to laboratory for analysis. The plants were botanically identified in the Institute of Biodiversity Conservation and 
Biosafety of Slovak University of Agriculture in Nitra. Samples were identified as MN (Morus nigra) and appropriate number.

\subsection{Morphological analysis of black mulberry fruits}

The following properties were measured by morphological analysis:

a) Fruit length in mm, $n=10$ measurement was performed from the base to the apical part of the fruits and was measured with digital caliper gauge with a sensitivity of $0.05 \mathrm{~mm}$ (Proteco, Czech Republic)

b) Fruit width in $\mathrm{mm}, n=10$, measurement was done in the middle part of the fruits and was measured with digital caliper gauge with a sensitivity of $0.05 \mathrm{~mm}$ (Proteco, Czech Republic)

c) Fruit weight in $\mathrm{mg}, n=30$, was detected for matured fruits by measureing of weight with analytical scales (Kern ADB-A01S05, Germany).

\subsection{Chemicals}

All the chemicals used were of analytical grade and were purchased from Sigma-Aldrich (St. Louis, MO, USA) and Centralchem (Slovakia).

\subsection{Preparation of black mulberry products}

The tested fresh fruits and food products were made by traditional procedure using the processing methods of native inhabitants of village Pukanec in Slovakia.

a) Fresh matured fruits were randomly selected from the obtained fruits.

b) Natural juice was obtained from fresh fruits without thermal treatment. For this processing, the homogeneously ripened fruits were selected and mixed with a blender. A sieve was used to eliminate the seeds (Fig. 1c), the extract was then pressed softly in order to increase the yield.

c) Natural juice was obtained from fresh fruits using hot steam.

d) Fresh fruits were conserved in honey with a ratio of $1: 3$ without sterilization.

e) Fresh fruits were conserved in honey with a ratio of $1: 3$ with subsequent sterilization at $85^{\circ} \mathrm{C}$.

f) Jam was produced from fresh fruits by traditional procedure (using sucrose with ratio 1:5).

g) Jelly was produced from fresh fruits by traditional procedure (using sucrose ratio 1:6).

h) Syrup was produced from fresh fruits by traditional procedure with addition of sucrose with a ratio of $1: 8$.

i) Liqueur was made from fresh fruits by traditional procedure with $90 \%$ ethanol (final concentration of ethanol in liqueur was $22 \%$ )

j) Compote was made from fresh fruits with sucrose with a ratio of $1: 2$.

k) Wine was made from fermented fresh fruits and production time was 21 days until the concentration of $12 \%$ ethanol was reached. Briefly, the black mulberry juice was put in 10 -L fermentation tanks at $20^{\circ} \mathrm{C}$ with a stable atmosphere in dark room. Fermentation method consisted of the free fermentation produced by the native yeast present in the black mulberry juice.

From each of the products three samples were tested.

\subsection{Free radical scavenging activity}

Free radical scavenging activity was measured by 2,2-diphenyl-1-picrylhydrazyl (DPPH) according to BrandWilliams et al. (1995) [16]. An amount of $0.1 \mathrm{~mL}$ of sample of juice, wine, syrup, liqueur; sample of fruits conserved by honey, jam, compote and jelly was homogenized in a mortar and $1 \mathrm{~g}$ of the blended mass was 

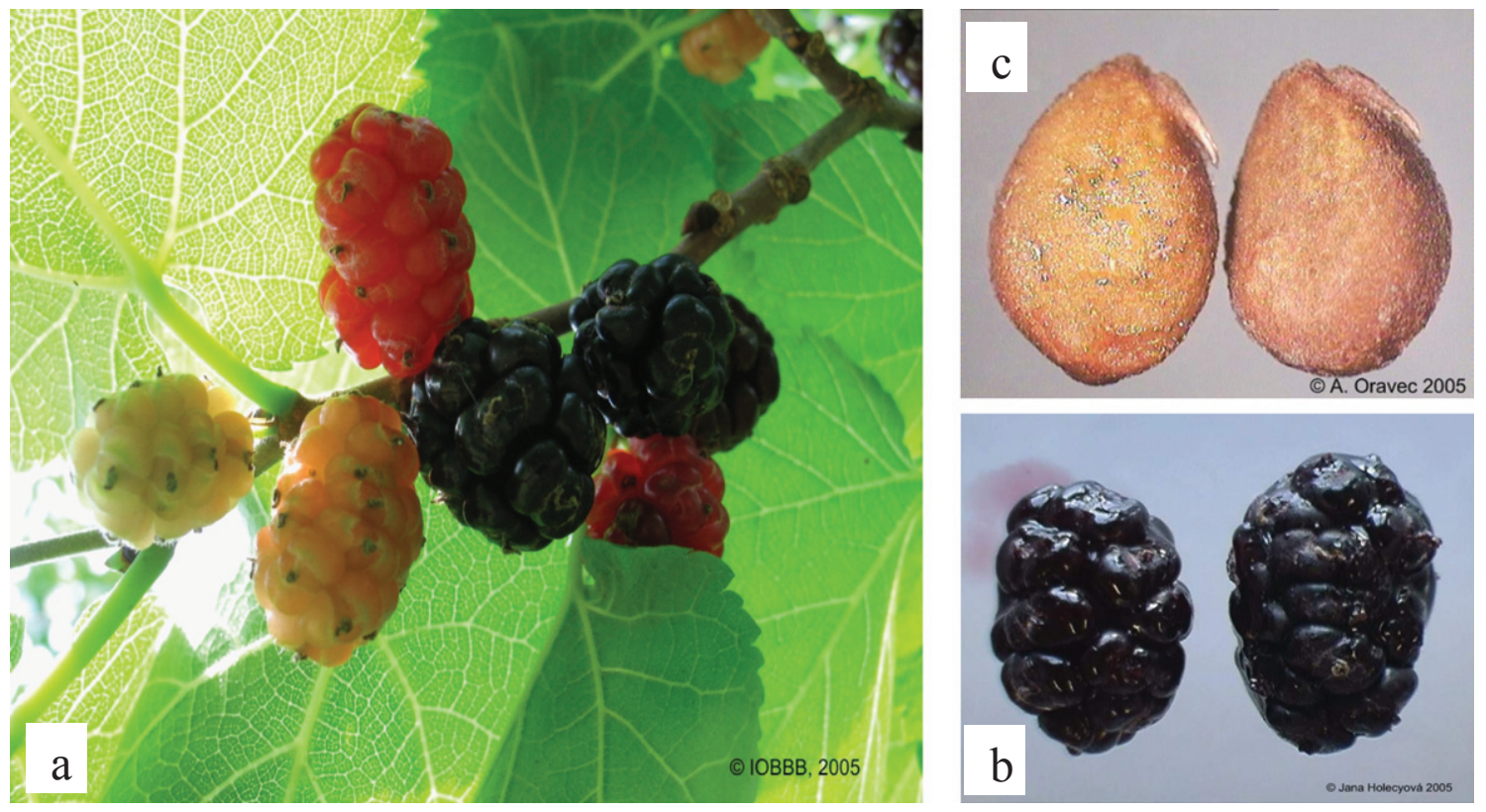

Fig. 1. The gradual ripening of the fruit (a), the shape of fruit (b), and seeds (c) of black mulberry (Morus nigra L.). Photo J. Holecyova and A. Oravec.

extracted for $5 \mathrm{~min}$ in $100 \mathrm{ml}$ of distilled water, filtrated and after filtration the extract was used for measuring. For detection of free radical scavenging activity, the extract was mixed with $3.9 \mathrm{~mL}$ of DPPH radical $(0.025 \mathrm{~g}$ was soluble in $96 \%$ ethanol and diluted as needed). Absorbance was registered at $515 \mathrm{~nm}$ in regular time intervals until the reaction equilibrium was reached (10 minutes) by using spectrophotometer (Genesys 20 UV-VIS, USA). The DPPH scavenging activity (\% inhibition) was calculated to fresh matter (FM) by using of following equation:

$$
\% \operatorname{Inh}=\frac{A_{0}-A_{1}}{A_{0}} 100
$$

where $A_{0}$ - absorbance of control reaction and $A_{1}$ - absorbance in presence of the sample.

\subsection{Total anthocyanin content}

Total anthocyanin content was determined by the pH-differential method as described Wrolstad, (1993) [17]. For preparation of extract, an amount of $1 \mathrm{~g}$ of sample was extracted with $40 \mathrm{~mL}$ of solvent ethanol : $0.1 \mathrm{M} \mathrm{HCl}$ $-85: 15 \%$, v:v, centrifuged and supernatant was used for measuring. The extract of sample were diluted with buffer and the absorbance was read at 520 and $700 \mathrm{~nm}$ with spectrophotometer (Jasco V-560 UV/VIS, Japan). Content of anthocyanin was calculated in $\mathrm{mg}^{-1}$ per $\mathrm{dm}^{-3}$ of fresh matter (FM) as pelargonidin-3-glucoside with molar absorption coefficient of $22400 \mathrm{M}^{-1} \mathrm{~cm}^{-1}$ and molecular weight of 433.2 Da.

\subsection{Detection of $p H$ values}

The detection of the $\mathrm{pH}$ value of samples was carried out by $\mathrm{pH}$ meter (Mettler Toledo FE20K, Germany) 


\subsection{Content of reducing sugar}

Reducing sugar content was determined spectrophotometrically at $540 \mathrm{~nm}$ by the method using 3, 5-dinitrosalicylic acid [18]. Reducing sugar content was calculated as glucose equivalent in $\mathrm{mg}^{-1} \mathrm{per} \mathrm{kg}^{-1}$ of fresh matter.

\subsection{Content of ascorbic acid}

Ascorbic acid content was determined using 5\% metaphosphoric acid (MPA) as the extracting solution according to the method of Campos et al. [19] with modifications. Content of ascorbic acid was expressed in $\mathrm{mg}^{-1}$ per $100 \mathrm{~g}^{-1}$ of fresh matter.

\subsection{Statistical analysis}

Experimental data on fruit traits were evaluated by basic statistical variability indicators using the Microsoft ${ }^{\mathrm{TM}}$ Excel ${ }^{\circledR}$ program. Dependency rate between the tested traits was expressed using the linear correlation analysis exploiting the relevant software [20].

\section{Results and discussion}

\subsection{Morphological characterization of fruits}

The medium fruit weight ranged from $1.42 \mathrm{~g}(\mathrm{MN}-14)$ to $7.26 \mathrm{~g}(\mathrm{MN}-1)$. Results on distinct differences between the traits of tested genotypes are shown in Table 1. Variation coefficients indicate medium (10.55-MN-17) and very high degree $(36.22-\mathrm{MN}-8)$ of variability for the trait. Variability of fruits size is strongly affected by the genotype but in the same time should be taken into account the conditions of maturation. Black mulberry fruits are maturing gradually (Fig. 1a), therefore the fruits are picked up in a time period of 2, even 4 weeks and this could affect the variability of size of berries (Fig. 1b).

Medium fruits length ranged from $13.51 \mathrm{~mm}(\mathrm{MN}-14)$ to $29.20 \mathrm{~mm}(\mathrm{MN}-12)$. The variation coefficients referred from low (5.76\% with $\mathrm{MN}-17$ ) to high degree of variability (25.67\% with MN-45). Medium fruits width ranged from $11.88 \mathrm{~mm}(\mathrm{MN}-14)$ to $21.12 \mathrm{~mm}(\mathrm{MN}-2)$. The variation coefficient showed the values from low degree (3.59\% for MN-27) up to high degree of variability (24.39\% for MN-8). Significant differences among the genotypes of all tested fruit traits were observed $(P<0.001)$.

Black mulberry fruit size usually is characterized by the weight, height and width. The results of the present study (1.42-7.26g) differ from the previous experiments in which the weight reported was from 2.96 to $6 \mathrm{~g}$ $[21,22]$. However, the length and width of fruits in our report (from 13.51 to $29.20 \mathrm{~mm}$ and from 11.88 to $21.12 \mathrm{~mm}$, respectively) correspond to reports of other authors with the the length accounting $14-35 \mathrm{~mm}$ and width 13-22 $\mathrm{mm}[23,24]$.

Linear correlation between the evaluated traits indicates very strong positive correlation between the fruits weight and length with correlation coefficient of $r=0.88$ (Table 2). The positive correlation was identified between the fruits weight and width with correlation coefficient of $r=0.81$ ) and between the fruits length and width with correlation coefficient of $r=0.84$.

\subsection{Content of reducing sugar, ascorbic acid and $p H$ values of black mulberry fruits and derived food products}

Yield of juice from unprocessed fruits was from 68 to $72 \%$ and from 58 to $69 \%$ after pre-heating of fruits at $75^{\circ} \mathrm{C}$. Similar results we reported by Yilmaz et al. (2012) [24], who tested the selected mulberry genotypes and obtained the juice yield of $39-72 \%$. 
Table 1

Variability of selected fruit traits of black mulberry (Morus nigra L.) genotypes

\begin{tabular}{|c|c|c|c|c|c|c|c|c|c|c|c|}
\hline \multicolumn{6}{|c|}{ Genotypes with the lowest values (g) } & \multicolumn{6}{|c|}{ Genotypes with the highest values (g) } \\
\hline Genotype & $n$ & Min. & Max. & $x$ & $\mathrm{~V} \%$ & Genotype & $n$ & Min. & Max. & $x$ & $\mathrm{~V} \%$ \\
\hline \multicolumn{12}{|c|}{ Fruits weight (mg) } \\
\hline $\mathrm{MN}-14$ & 20 & 0.95 & 2.35 & 1.42 & 29.23 & $\mathrm{MN}-1$ & 20 & 4.17 & 10.69 & 7.26 & 34.22 \\
\hline MN-31 & 20 & 2.09 & 3.93 & 3.11 & 17.78 & $\mathrm{MN}-2$ & 20 & 4.48 & 9.12 & 6.91 & 22.69 \\
\hline MN-6 & 20 & 2.44 & 4.58 & 3.37 & 25.57 & $\mathrm{MN}-26$ & 20 & 2.79 & 8.17 & 6.50 & 25.24 \\
\hline $\mathrm{MN}-17$ & 20 & 2.98 & 3.99 & 3.37 & 10.55 & $\mathrm{MN}-10$ & 20 & 5.13 & 7.98 & 6.45 & 14.31 \\
\hline MN-44 & 20 & 2.05 & 4.52 & 3.41 & 22.49 & $\mathrm{MN}-12$ & 20 & 4.28 & 7.41 & 6.37 & 17.66 \\
\hline \multicolumn{12}{|c|}{ Fruits height (mm) } \\
\hline $\mathrm{MN}-14$ & 20 & 11.00 & 16.29 & 13.51 & 12.11 & $\mathrm{MN}-12$ & 20 & 23.63 & 33.51 & 29.20 & 13.22 \\
\hline MN-31 & 20 & 15.68 & 22.73 & 19.30 & 10.14 & MN-1 & 20 & 20.84 & 38.66 & 29.00 & 20.84 \\
\hline MN-17 & 20 & 18.27 & 21.48 & 20.19 & 5.76 & $\mathrm{MN}-36$ & 20 & 22.13 & 33.91 & 28.82 & 10.48 \\
\hline $\mathrm{MN}-28$ & 20 & 14.05 & 27.30 & 20.29 & 22.08 & MN-7 & 20 & 18.74 & 36.73 & 28.44 & 21.36 \\
\hline $\mathrm{MN}-45$ & 20 & 13.45 & 29.05 & 20.72 & 25.67 & $\mathrm{MN}-26$ & 20 & 17.25 & 32.96 & 27.94 & 15.12 \\
\hline \multicolumn{12}{|c|}{ Fruits width (mm) } \\
\hline MN-14 & 20 & 9.55 & 13.71 & 11.88 & 11.05 & $\mathrm{MN}-2$ & 20 & 17.14 & 30.15 & 21.12 & 19.36 \\
\hline MN-31 & 20 & 12.83 & 17.10 & 14.74 & 10.01 & MN-1 & 20 & 15.19 & 22.03 & 19.32 & 10.94 \\
\hline MN-28 & 20 & 10.38 & 19.26 & 14.94 & 19.69 & MN-36 & 20 & 17.64 & 20.24 & 18.78 & 4.23 \\
\hline $\mathrm{MN}-23$ & 20 & 13.21 & 19.05 & 15.12 & 11.92 & MN-7 & 20 & 16.47 & 21.41 & 18.76 & 9.02 \\
\hline $\mathrm{MN}-21$ & 20 & 13.24 & 17.88 & 15.21 & 9.67 & $\mathrm{MN}-32$ & 20 & 16.67 & 21.01 & 18.66 & 7.53 \\
\hline
\end{tabular}

MN - Morus nigra; $n=$ Number of the individuals; Min. = Minimum value; Max. = Maximum value; $x=$ Arithmetic mean; V\% $=$ Coefficient of variation in $\%$.

Table 2

Correlation coefficients of linear correlation analysis among the morphological traits of black mulberry (Morus nigra L.) fruits

\begin{tabular}{|c|c|c|c|c|c|}
\hline$\underline{\mathrm{r}}$ & $\mathrm{S}_{\mathrm{r}}$ & Confidence interval $\mathrm{r}_{95 \%}$ & $\mathrm{r}^{2}$ & $\mathrm{~T}$ & Probability of $\mathrm{t}(\mathrm{p})$ \\
\hline \multicolumn{6}{|c|}{ Fruits weight $(\mathrm{g})-$ Fruits length $(\mathrm{mm})$} \\
\hline 0.888 & 1.369 & $0.810<=r>=0.935$ & 0.7890 & 13.3971 & 0.0000 \\
\hline \multicolumn{6}{|c|}{ Fruits weight $(\mathrm{g})-$ Fruits width $(\mathrm{mm})$} \\
\hline 0.817 & 0.844 & $0.697<=r>=0.892$ & 0.6681 & 9.8288 & 0.0000 \\
\hline \multicolumn{6}{|c|}{ Fruits length $(\mathrm{mm})-$ Fruits width $(\mathrm{mm})$} \\
\hline 0.842 & 0.789 & $0.7373<=r>=0.9081$ & 0.7102 & 10.8447 & 0.0000 \\
\hline
\end{tabular}

$\mathrm{r}$ - Pearsons correlation coefficient; $\mathrm{s}_{\mathrm{r}-}$ Standard error; 95\% Confidence interval; $\mathrm{r}^{2}$ - Coefficient of determination; $t$ - Test for the significance of the coefficient; probability of $\mathrm{t}(\mathrm{p})$.

Total amount of reducing sugars was from $6.50 \mathrm{mg} \cdot \mathrm{kg}^{-1}$ in wine to $60.01 \mathrm{mg} \cdot \mathrm{kg}^{-1}$ in jam. Low concentration of reducing sugars in wine could be explained with the transformation of sugars into alcohol. Jam, jelly and syrup processing needs the addition of sugar to the product for preservation purposes. The differences between the technologies of producing of different kind of product could be a reason for differences in sugar content. Ascorbic acid content ranged from $0.27 \mathrm{mg} .100 \mathrm{~g}^{-1}$ in wine to $1.10 \mathrm{mg} .100 \mathrm{~g}^{-1}$ in fruits in honey without sterilization process. In all thermally treated products the amount of ascorbic acid was less than in unprocessed 
Table 3

Average content of reducing sugars, anthocyanin, ascorbic acid and $\mathrm{pH}$ value of food products derived from black mulberry (Morus nigra L.) fruits

\begin{tabular}{lccc}
\hline Products & $\begin{array}{c}\text { Reducing sugar } \\
\text { content }\left(\mathrm{mg}^{-\mathrm{kg}^{-1}}\right)\end{array}$ & $\mathrm{pH}$ value & $\begin{array}{c}\text { Ascorbic acid } \\
\text { content }(\mathrm{mg} .100 \mathrm{~g}-1)\end{array}$ \\
\hline Juice gained by centrifugation & 17.24 & 3.47 & 0.87 \\
Juice gained by thermal processing & 20.04 & 3.43 & 0.69 \\
Fruits conserved in honey without sterilization & 20.00 & 3.44 & 1.10 \\
Sterilized fruits in honey & 25.00 & 3.45 & 1.03 \\
Jam & 60.01 & 3.31 & 0.76 \\
Canned fruit & 11.26 & 3.50 & 0.90 \\
Liqueur & 31.50 & 3.69 & 0.73 \\
Syrup & 58.50 & 3.37 & 0.36 \\
Jelly & 54.50 & 3.28 & 0.66 \\
Wine & 6.50 & 3.68 & 0.27 \\
\hline
\end{tabular}

Table 4

Anthocyanin content and free radical scavenging activity (inhibition in \%) in fruits of different black mulberry (Morus nigra L.) genotypes

\begin{tabular}{lcc}
\hline Genotype & Anthocyanin content $\left(\mathrm{mg} \cdot \mathrm{dm}^{-3}\right)$ & Inhibition $(\%)$ \\
\hline MN-1 & $146.3^{\mathrm{c}}$ & $71.79^{\mathrm{a}}$ \\
MN-2 & $138.0^{\mathrm{c}}$ & $72.92^{\mathrm{a}}$ \\
MN-26 & $178.0^{\mathrm{b}}$ & $68.95^{\mathrm{b}}$ \\
MN-14 & $254.0^{\mathrm{a}}$ & $63.00^{\mathrm{b}}$ \\
MN-31 & $243.0^{\mathrm{a}}$ & $69.04^{\mathrm{ab}}$ \\
MN-6 & $166.0^{\mathrm{b}}$ & $71.68^{\mathrm{a}}$ \\
MN-17 & $173.0^{\mathrm{b}}$ & $72.83^{\mathrm{a}}$ \\
\hline
\end{tabular}

${ }^{\mathrm{ab}}$ Means within a column with the same letters are not significantly different according to Tukey's multiple range test $(P \leq 0.05)$.

foods (Table 3). In all tested food products the $\mathrm{pH}$ value was acidic and varied from 3.28 in jelly to 3.69 in liqueur. Previously reported $\mathrm{pH}$ value for juice made from Morus alba fruits was from 4.5 to 5.4, for Morus rubra juice from 5.6 to 5.8 and for Morus nigra juice from 2.1 to 3.2. Morus nigra genotypes generally had the highest acidity values and the $\mathrm{pH}$ values corresponds to our findings [23, 24].

\subsection{Content of anthocyanin and free radical scavenging activity in black mulberry fruit}

Mulberry is highly esteemed on the soft drink market, although the biological and pharmacological effects are still only poorly defined and the anthocyanins is highlighted as-the most important components [25]. The content of anthocyanin was determined in selected seven genotypes of black mulberry fruit - MN-1, MN-2, MN-26 with big fruit weight and genotypes MN-14, MN-31, MN-6 a MN-17 with small fruit weight (Table 1). In tested fruit samples the anthocyanins content ranged from 138.0 to $254.0 \mathrm{mg} . \mathrm{dm}^{-3}$ (Table 4). Genotypes with bigger fruit weight showed lower amounts of anthocyanin content $\left(138.0-178.0 \mathrm{mg} . \mathrm{dm}^{-3}\right)$ in comparison to the genotypes with smaller fruit weight $\left(166.0-254.0 \mathrm{mg} . \mathrm{dm}^{-3}\right)$. Differences between the genotypes were significant and the content of the anthocyanin was significantly higher in genotypes with lower fruit weight $(P \leq 0.05)$. 
Table 5

Anthocyanin content and free radical scavenging activity (inhibition in \%) in traditional black mulberry food products

\begin{tabular}{lcc}
\hline Tested products made of mulberry fruits & $\begin{array}{c}\text { Anthocyanins content } \\
\left(\mathrm{mg.dm}^{-3}\right)\end{array}$ & Inhibition (\%) \\
\hline Juice gained by centrifugation & $106.4^{\mathrm{a}}$ & $67.83^{\mathrm{ab}}$ \\
Juice gained by thermal processing & $74.3^{\mathrm{b}}$ & $51.17^{\mathrm{d}}$ \\
Fruits conserved in honey without sterilization & $92.1^{\mathrm{a}}$ & $70.46^{\mathrm{a}}$ \\
Sterilized fruits in honey & $49.7^{\mathrm{c}}$ & $74.02^{\mathrm{a}}$ \\
Jam & $94.5^{\mathrm{a}}$ & $71.22^{\mathrm{a}}$ \\
Jelly & $90.0^{\mathrm{a}}$ & $69.67^{\mathrm{a}}$ \\
Syrup & $46.9^{\mathrm{c}}$ & $62.99^{\mathrm{b}}$ \\
Liqueur & $37.7^{\mathrm{c}}$ & $57.87^{\mathrm{bc}}$ \\
Canned fruit & $23.8^{\mathrm{cd}}$ & $66.16^{\mathrm{ab}}$ \\
Wine & $21.4^{\mathrm{cd}}$ & $50.81^{\mathrm{d}}$ \\
\hline
\end{tabular}

${ }^{\mathrm{ab}}$ Means within a column with the same letters are not significantly different according to Tukey's multiple range test $(P \leq 0.05)$.

Detection of free radical scavenging activity showed strong effect of black mulberry fruit to eliminate the synthetic radical with values ranged from 63.00 to $72.92 \%$ (Table 4). However, the significant differences in free redical scavenging activity between the bigger and smaller fruits were not identified $(P>0.05)$. Our results also showed that there were no correlation between the anthocyanin content and free radical scavenging activity. This observation could be explained with different maturity degree of the fruits.

The antioxidant properties and phytotherapeutic effects of black mulberry fruits are caused by the presence of significant concentration of anthocyanins. Our study confirms that the fruit is a valuable source of natural antioxidants; however, instability during the processing and storage must be taken into account. Heating cause partial degradation and polymerization resulting in a decolourization of the product [24-28].

\subsection{Anthocyanin content and free radical scavenging activity in black mulberry food products}

In black mulberry-derived food products the anthocyanin content ranged from $21.4 \mathrm{mg} \cdot \mathrm{dm}^{-3}$ in wine to $106.4 \mathrm{mg} \cdot \mathrm{dm}^{-3}$ in fresh juice produced using kitchen juicer (Table 5). Thermal processing strongly affect the products resulting in lower concentration of anthocyanin - in juice produced by steam it decreased from 106.4 to $74.3 \mathrm{mg} / \mathrm{dm}^{3} \mathrm{FM}$, after sterilization of fruits in honey the decrease from 92.1 to $49.7 \mathrm{mg} . \mathrm{dm}^{-3} \mathrm{FM}$ was observed. In the case of syrup the final content was $46.9 \mathrm{mg} \cdot \mathrm{dm}^{-3} \mathrm{FM}$, in liqueur $37.7 \mathrm{mg} \cdot \mathrm{dm}^{-3} \mathrm{FM}$ and/or in compote $23.8 \mathrm{mg} \cdot \mathrm{dm}^{-3} \mathrm{FM}$, and the differences in content of anthocyanon between the raw material and processed products were significant $(P<0.05)$. Important to point out that the jam and jelly contained $94.5 \mathrm{mg} . \mathrm{dm}^{-3} \mathrm{FM}$ and $90.0 \mathrm{mg} \cdot \mathrm{dm}^{-3} \mathrm{FM}$, respectively. In these products the content of anthocyanins changed relatively in less extent and this could be explained by an extreme juice thickening due to water evaporation.

Mulberry fruit contain the high amount of anthocyanins and it is generally used for nutritive and therapeutic purposes. It has been reported that cyanidin 3-rutinosid and cyanidin 3-glucosid of Morus alba L. exerted depending on applied concentration an inhibitory effect on the migration and invasion of A549 carcinome cells in the human lungs with massive metastasis without cytotoxicity. These results indicate the anthocyanins has potential application in vitro to decrease the cancer cells invasion, therefore could be an important factor in a cancer therapy $[29,30]$. Flavonoids are the most frequently occurring forms of polyphenolic compounds in the human food like fruits, vegetable, tea and red wine. As flavonoids exhibit various pharmacologic properties including anti-oxidative, antiviral and antiinflammation mode of action [31-33]. the people are instigated to consume the 
foods rich in flavonoids. Morin (3, 5, 7, 2', $4^{\prime}$-pentahydroxyflavone) is a flavonoid present in mulberry and several herbs. The former studies declared that morin affect the inflammation process in the case of active macrophages and is able to reduce the risk of septic shock [34-36].

Free radical scavenging activity in black mulberry food products (Table 5) ranged from $50.81 \%$ in berry wine to $74.02 \%$ in sterilized fruits in honey. High level of free radical scavenging activity in fruit in honey is strongly influenced by honey, which is rich for antioxidant compounds and also compounds with antimicrobial activity $[37,38]$. Generally could be concluded, there is no direct correlation between the content of anthocyanin and the antioxidant activity of tested food products. The antioxidant activities of mulberry fruit and related products could be explained with the presence of other components with they share like the phenolic acid, vitamins, and mineral compounds. Similar findings also reported Kamiloglu et al. (2013) [39], who compared antioxidant activity and content of polyphenol in fresh black mulberry fruit with related products like dried fruit, ice cream, molasses, juice, syrup, wine. Kamiloglu et al. (2013) [39] found significantly higher value of anthocyanins, flavonoids, polyphenols and antioxidant activity in fresh fruits in comparison to processed products. In future, for better understanding of pharmacokinetics of plant is necessary to intensify the studies, which are oriented on the mode of absorption and effect of mulberry antioxidants on the organisms. This will be helpful to evaluate the beneficial potential of this plant for human health.

\section{Conclusion}

Results from this study confirm that the black mulberry (Morus nigra) fruits can be an important source of biologically active compounds. Statistically significant differences in fruits size, anthocyanin content (138.0 $\left.254.0 \mathrm{mg} . \mathrm{dm}^{-3} \mathrm{FM}\right)$ and free radical scavenging activity $(63.00-72.92 \% \mathrm{FM})$ were observed between different traits. In several Slovakia regions the black mulberry is used for preparation of food products which can possess the phytotherapeutic effect to human health. The evaluation of 10 food products revealed the presence of anthocyanin and the content ranged from 21.4 in wine to $106.4 \mathrm{mg} \cdot \mathrm{dm}^{-3}$ in fresh juice. Remarkable antioxidant activity of products from 50.81 in wine to $74.02 \%$ in fruits sterilized in honey were reported. The reduction of anthocyanin content and the antioxidant activity is caused by the thermal processing of fruits and/or juices. The results confirmed that the traditional technologies applied by inhabitants of Slovakia enabled to keep the high nutritional quality of fruits as well as of food products, what is connected with their beneficial phytotherapeutic effects.

\section{Acknowledgments}

This work was supported by the Operational Programme Research and Development of the European Regional Development Fund in the frame of the project "Support of technologies innovation for special bio-food products for human healthy nutrition” ITMS 26220220115. The authors also gratefully acknowledge to Alex Oravec and Jana Holecyova for making the photos.

\section{References}

[1] Usmanghani K, Saeed A, Alam T. Indusyunic Medicine, Department of Pharmacognosy. Pakistan: University of Karachi, 1997, p. 601.

[2] Hojjatpanah G, Fazaeli M, Emam-Djomeh Z. Effects of heating method and conditions on the quality attributes of black mulberry (Morus nigra) juice concentrate. Int J Food Sci Technol. 2011;46:956-62.

[3] Ercisli S, Tosun M, Duralija B, Voća S, Sengul M, Turan M. Phytochemical content of some black (Morus nigra L.) and purple (Morus rubra L.) mulberry genotypes. Food Technol Biotechnol. 2010;48:102-06.

[4] Kafkas S, Özgen M, Doğan Y, Özcan B, Ercişli S, Serçe S. Molecular characterization of mulberry accessions in Turkey by AFLP markers. J Amer Soc Hort Sci. 2008;133:593-7. 
[5] Benčat' F. Black mulberry and its importance in CHKO Štiavnické vrchy. Proceedings of the seminar on the 20th anniversary of the declaration of the CHKO Štiavnické vrchy. Banská Štiavnica: CHKO Štiavnické vrchy. 1999, pp. 95-105.

[6] Koyuncu F, Koyuncu MA, Yidrm F, Vural E. Evaluation of black mulberry (Morus nigra L.) genotypes from lakes region, Turkey. European J Hort Sci. 2007;69:125-31.

[7] Abdalla ES. The biological benefits of black mulberry (Morus nigra) intake on diabetic and non diabetic subjects. Res J Agric Biol Sci. 2006;2:349-57.

[8] Imran M, Khan H, Shah M, Khan R, Khan F. Chemical composition and antioxidant activity of certain Morus species. J Zhejiang Univ Sci. B 2010;11:973-80.

[9] Hussain T. Food composition tables for Pakistan. Govt. Of Pakistan, Ministry of Planning and Development, Islamabad. 1985 , p. 67.

[10] Kresánek J, Krejča J. Atlas of medicinal herbs and forestry fruit. Martin: Osveta, 1977, pp. 386-387.

[11] Bown D. Encyclopedia of Herbs and their Uses. London: Dorling Kindersley Limited, 2003, p. 448.

[12] Mucimapura S, Wattanathorn J, Thongrong S, Chaisiwamongkol K, Sripanidkulchai B. Morus alba enhanced functional recovery after sciatic nerve crush injury. Am J Agric Biol Sci. 2010;5:294-300.

[13] Duke JA, Ayensu ES. Medicinal Plants of China. Michigan: Reference Pubns. 1985, p.704.

[14] Ercisli S, Orhan E. Chemical composition of white (Morus alba), red (Morus rubra) and black (Morus nigra) mulberry fruits. Food Chem. 2003;103:1380-84.

[15] Odyová P. The big atlas of medicinal herbs. Martin: Osveta, 1993.

[16] Brand-Williams W, Cuvellier ME, Berset C. Use of a free radical method to evaluate antioxidant activity. Lebensm Wiss Technol. 1995;28:5-30.

[17] Wrolstad RE. Color and pigment analysis in fruit products. Station Bulletin 624, Corvallis, 2nd. Edn. 1995.

[18] Miller GL. Use of dinitrosalicylic acid reagent for determination of reducing sugar. Anal Chem. 1959;31:426-28.

[19] Campos FM, Ribeiro SRM, Lucia CMD, Pinheiro-Santana PM, Stringheta PC. Optimization of methodology to analyze ascorbic and dehydroascorbic acid in vegetables. Quim Nova. 2009;32:87-1.

[20] Armitage P. Statistical Methods. Medical Research. Blackwell Scientific Publications. Oxford, 1971, pp. $189-207$.

[21] Vanička J, Soják Š, Cvopa J. Genofond - original cultivars of fruit. Záhradkár. 1991;38:28.

[22] Holecyová J, Brindza J, Stehlíková B. Variability of some properties of black mulberry fruit and leaves. Proceedings - New findings from genetics and breeding of agricultural plants. VÚRV, Piešt'any, pp. 193-196. 2004.

[23] Benčat' T, et al. Biometric data about black mulberry fruit from Pukanec. In Benčat', Tibor,. (ed.), Introduction and acclimatization of trees in Central European conditions, Poniky : Vydavateil'stvo Partner, pp. 216-221. 2004

[24] Yilmaz KU, Zengin Y, Ercisli S, Demirtas MN, Kan T, Nazli AR. Morphological diversity on fruit characteristics among some selected mulberry genotypes from Turkey. J Anim Plant Sci. 2012;22:211-14.

[25] Kintlerová A, et al. Small fruit - source of food colorants. Záhradníctvo. 1996;21:10-11.

[26] Gerasopoulos D, Stavorulakis GM. Quality characteristics of four mulberry (Morus sp) cultivars in the area of Chania, Greece. J Sci Food Agric. 1997;3:261-64.

[27] Markakis P. Stability of anthocyanins in foods. Ch. 6 In Anthocyanins as Food Colors. P. Markakis (Ed.). Academic Press, New York. 1982.

[28] Tsai PJ, Huang HP. Effect of polymerization on the antioxidant capacity of anthocyanins in roselle. Food Res Int. 2004;37:313-18.

[29] Yang CH, Tsai TC. Anthocyanins in mulberry fruit. In Food Sci. 1994;21:319-30.

[30] Maskan M, Gogus F. Sorption isotherms and drying characteristics of mulberry (Morus alba). J Food Engineer. 1998;37:437-49.

[31] Chen P, Chu S, Chiou H, et al. Mulberry anthocyanins, cyanidin 3-rutinoside and cyanidin 3-glucoside, exhibited an inhibitory effect on the migration and invasion of a human lung cancer cell line. Cancer Lett. 2015;235:248-59.

[32] Scalzo J, Politi A, Pellegrini N, Mezzetti B, Battino M. Plant genotype affects total antioxidant capacity and phenolic contents in fruit. Nutrition. 2005;21:207-13.

[33] Forbes-Hernández TY, Giampieri F, Gasparrini M, Mazzoni L, Quiles JL, Alvarez-Suarez JM, Battino M. The effects of bioactive compounds from plant foods on mitochondrial function: A focus on apoptotic mechanisms. Food Chem Toxic. 2014;68: 154-82.

[34] Middleton EJ, Kandaswami C, Theoharides TC. The effects of plant flavonoids on mammalian cells: Implications for inflammation, heart disease, and cancer. Pharmacol Rev. 2000;52:673-751.

[35] Fang SH, Hou YC, Chang WC, Hsiu SL, Chao PDL. Morin sulfates/glucuronides exert anti-inflammatory activity on activated macrophages and decreased the incidence of septic shock. Life Sci. 2003;74:743-56.

[36] Katsube T, Iwamaka N, Kawano Y, Yamazaki Y, Shiwaku K, Yamane Y. Antioxidant flavonol glycosides in mulberry (Morus alba L.) leaves isolated based on LDL antioxidant activity. Food Chem. 2005;97:25-31. 
[37] Kačániová M, Fatrcová-Šramková K, Nôžková J, Melich M, Kadási-Horáková M, Kňazovická V, Felsöciová S, Kunová S, Máriássyová M. Antiradical activity of natural honeys and antifungal effect against Penicillium generea. J Environ Sci Health B. 2011;46:92-6.

[38] Fatrcová-Šramková K, Nôžková J, Máriássyová M, Kačániová M, Dudríková E. Reduction power, polyphenols content and antimicrobial activity of honey. Chem listy. 2008;15:628-9.

[39] Kamiloglu S, Serali O, Unal, N, Capanoglu E. Antioxidant activity and polyphenol composition of black mulberry (Morus nigra L.) products. J Berry Res. 2013;3:41-51. 